International

Journal of

Sustainable

Construction

Engineering and

Technology

\title{
Managing Uncertainty from Planning and Design to Construction Process of Building Refurbishment Projects: A Proposed Conceptual Approach
}

\author{
RidzuanYacob $^{1}$, Masran Saruwono ${ }^{1}$, Zulhabri Ismail ${ }^{1 *}$ \\ ${ }^{1}$ Faculty of Architecture, Planning \& Surveying, \\ Universiti Teknologi MARA, Shah Alam, Malaysia \\ *Corresponding Author \\ DOI: https://doi.org/10.30880/ijscet.2019.10.01.007 \\ Received 12 January 2019; Accepted 24 May 2019; Available online 01 June 2019
}

\begin{abstract}
The number of building refurbishment projects in Malaysia has increased significantly over the past few years. Empirical data from previous research confirmed that managing Building Refurbishment Project (BRP) is demanding and risky which is inherent in Uncertainty Factor (UF) associated with unforeseen elements, mostly comprising of actual cost that exceeds budget. This occurs when they involve structural modifications with sensitive, dangerous, difficult operations with large number of sub-contractors, and the high number of building services that has always been identified as one of the reasons for poor performance. The reasons were as stated because UF of construction process was less emphasised compared to planning and design process. This emphasis is however questionable in the real world as the UF is consistent throughout the BRP life cycle. This paper aims to determine the UF of construction process and the relationship with BRP performance. The method used for this study is based on a comprehensive review of related journal papers, book chapters and conference papers from 1997 to 2019, from which 125 articles were identified and 53 papers were subsequently selected for further analysis. This study concluded that UF of construction process is indeed one of the most important factors that influence the performance of BRP. On that basis, there is still room for improving the level of BRP performance. The findings of this study form the foundation for an extended investigation to identify UF specifically in the construction process to serve as a guide in managing the UF and improving BRP performance in Klang Valley.
\end{abstract}

Keywords: building refurbishment project, construction process, uncertainty, project performance

\section{Introduction}

Building Refurbishment Project (BRP) is another way of giving a building a new lease of life after it has reached the end of its initial purpose or when it could not fulfill what is expected of it. BRP is determined as one of the most important economic drivers in Malaysian construction industry. Yacob, Rahmat, Saruwono, \& Ismail (2017) defined BRP as making use of what is usable from the old building stock that is valuable in its own right. BRP can be broadly categorised into two. The first category refers to works that bring back the building to its original design performance which involves repair, rehabilitation, and restoration. Meanwhile, the second category is described as works that upgrade the original design performance, which includes extension, renovation, improvement, retrofit, modernisation, and conversion (Rahmat, 2008). 
Rahmat and Ali (2009) stated that in many developed countries such as the United Kingdom and Germany, this sector contributes to about half of the construction output. A similar trend has been growing in Malaysia. The Construction Industry Development Board of Malaysia (2015) reported that the BRP contributes about 17 percent of the total output of the construction industry and is steadily increasing annually. Ali, Kamaruzzaman and Zulkiflee, (2010), however, observed that many of the refurbishment work carried out was unreported, especially those undertaken by individual homeowners who had carried out illegal renovation works which means the actual number should be higher.

Managing BRP is demanding because of the Uncertainty Factor (UF) inherent in BRP, the presence of many unforeseen elements; more risky operations especially when they involve structural modifications; and the presence of obstructive building services (Ali, 2014; Ali, Kamaruzzaman, \& Salleh, 2009; Ali \& Zakaria, 2012; Yacob et al., 2017). In addition, Rahmat and Ali (2009) emphasised that the UF of BRP are constantly present throughout the project life cycle. Compared with a new build, BRP is different and requires a more flexible and integrated approach.

As observed by Odimabo (2018), there is a difference between risk and uncertainty, where a risk is subjected to investigation and known probability; whereas, UF refers to events for which specifying numerical likelihood is impracticable. The lack of understanding on the nature of BRP has caused many designers and contractors to manage BRP the way they deem suitable. Therefore, cost and time overruns are considered very common in BRP (Ali et al., 2010).Hence, the actual value of refurbishment works could be higher than reported.

\section{Background to the Study}

Managing the construction process of a BRP is important because of the demands for performance which include cost, time, quality, and safety. Additionally, the comfort of the occupants and the neighbours is also crucial during the construction process (Yacob et al., 2017). The success of BRP is usually measured in terms of the effectiveness and efficiency of the construction process. Major causes of project delays include cost overrun and conflicts that tend to occur during the construction phase (Ali \&Zakaria, 2012; Noori, Saruwono, \& Adnan, 2016; Rahmat, 2008).

The results of previous research on managing UF of BRP in Malaysia from 1997 to 2019 show that $73 \%$ of research works were conducted on the planning and design process compared to $27 \%$ on the construction process. Since construction process is the most difficult process to manage (Jens, 2013; Quah, 1992; Yacob et al., 2017), modifying the management process slightly for a successful BRP performance is insufficient. Therefore, from a different perspective, this study suggests a new direction for future research to explore the Uncertainty Factor (UF) of construction process that can potentially influence the performance of Building Refurbishment Project (BRP).An overview of the existing process of managing BRP in Malaysia is illustrated in Table 1. The rest of this paper is organised as follows: (a) Methodology; (b) Findings and Discussion and (c) Conclusion and Recommendation.

Table 1 - Managing uncertainty factor of building refurbishment projects in Malaysia

\begin{tabular}{|c|c|c|c|c|}
\hline \multirow[b]{2}{*}{ No } & \multirow[b]{2}{*}{ Research Title } & \multicolumn{2}{|c|}{ BRP Life-Cycle } & \multirow[b]{2}{*}{ Author } \\
\hline & & $\begin{array}{l}\text { Planning } \\
\text { \& Design }\end{array}$ & Construction & \\
\hline 1 & $\begin{array}{l}\text { The planning and control Process of } \\
\text { Refurbishment Projects }\end{array}$ & $\sqrt{ }$ & & Rahmat (1997) \\
\hline 2 & $\begin{array}{l}\text { The design process of building refurbishment on } \\
\text { project performance }\end{array}$ & $\sqrt{ }$ & & $\begin{array}{l}\text { Ali } \\
\text { (2005)\&Irsyad et } \\
\text { al (2019) }\end{array}$ \\
\hline 3 & Uncertainty in the design process & $\sqrt{ }$ & & Ali et al., (2007) \\
\hline 4 & $\begin{array}{l}\text { The design process of building refurbishment } \\
\text { projects }\end{array}$ & $\sqrt{ }$ & & $\begin{array}{l}\text { Rahmat\&Ali, } \\
\text { (2009) }\end{array}$ \\
\hline 5 & $\begin{array}{l}\text { The characteristics of refurbishment projects in } \\
\text { Malaysia }\end{array}$ & $\sqrt{ }$ & $\sqrt{ }$ & Ali et al (2009) \\
\hline 6 & $\begin{array}{l}\text { Complexity in Refurbishment of Services System } \\
\text { for Historical Buildings in Malaysia }\end{array}$ & $\sqrt{ }$ & $\sqrt{ }$ & Ali, (2009) \\
\hline 7 & $\begin{array}{l}\text { The involvement of the key participants in the } \\
\text { production of project planning }\end{array}$ & $\sqrt{ }$ & & $\begin{array}{l}\text { Rahmat\& Ali, } \\
\text { (2010) }\end{array}$ \\
\hline 8 & $\begin{array}{l}\text { Design information in managing refurbishment } \\
\text { projects in Malaysia }\end{array}$ & $\sqrt{ }$ & & Ali (2010) \\
\hline 9 & $\begin{array}{l}\text { A Study on Design Performance of } \\
\text { Refurbishment Projects in Malaysia }\end{array}$ & $\sqrt{ }$ & & Ali et al (2010) \\
\hline 10 & $\begin{array}{l}\text { The effect of indoor environmental quality on } \\
\text { occupants' perception of performance: A case } \\
\text { study of refurbished historic buildings in Malaysia }\end{array}$ & $\sqrt{ }$ & $\sqrt{ }$ & $\begin{array}{l}\text { Kamaruzzaman et } \\
\text { al (2011) }\end{array}$ \\
\hline
\end{tabular}




\begin{tabular}{|c|c|c|c|c|}
\hline 11 & $\begin{array}{l}\text { Complexity of statutory requirements: case study } \\
\text { of refurbishment projects in Malaysia }\end{array}$ & $\sqrt{ }$ & & $\begin{array}{l}\text { Ali \& Zakaria, } \\
\text { (2012) }\end{array}$ \\
\hline 12 & $\begin{array}{l}\text { The designer in refurbishment projects: } \\
\text { implications to the compatibility of design }\end{array}$ & $\sqrt{ }$ & & $\begin{array}{l}\text { Ali \& Au-Yong } \\
\text { (2013) }\end{array}$ \\
\hline 13 & $\begin{array}{l}\text { Managing Refurbishment Projects Through } \\
\text { Selection of Procurement System: The Case of } \\
\text { Malaysia }\end{array}$ & $\sqrt{ }$ & & $\begin{array}{l}\text { Ali, Peng, et al., } \\
\text { (2014) }\end{array}$ \\
\hline 14 & $\begin{array}{l}\text { Conflict, Complexity, and Uncertainty in Building } \\
\text { Refurbishment Projects }\end{array}$ & $\sqrt{ }$ & $\sqrt{ }$ & $\begin{array}{l}\text { Noori et al., } \\
(2016)\end{array}$ \\
\hline 15 & $\begin{array}{l}\text { The effect of uncertainty factors and } \\
\text { refurbishment projects performance in relation to } \\
\text { leadership quality of project managers }\end{array}$ & $\sqrt{ }$ & $\sqrt{ }$ & $\begin{array}{l}\text { Yacob et al., } \\
(2017)\end{array}$ \\
\hline \multirow[t]{2}{*}{16} & $\begin{array}{l}\text { The influences of attributes, skills and knowledge } \\
\text { of managers on refurbishment project } \\
\text { performance }\end{array}$ & $\sqrt{ }$ & $\sqrt{ }$ & Ishak (2018) \\
\hline & Frequency & $73 \%$ & $27 \%$ & \\
\hline
\end{tabular}

\section{Methodology}

The initial stage of this study was to determine the UF of construction process of BRP. This exercise reviewed related papers to identify the relationships between UF of construction process and BRP performance. Articles retrieved for the literature review through search engines include Science Direct, Emerald Publishing, Taylor \& Francis, and Google Scholar. The literature search utilized a set of relevant keywords: "Building Refurbishment Project”, "Uncertainty", “Construction Process", and "Project Performance".

A Comprehensive Literature Review was conducted using the Literature Search Method adopted from (Papanti et al., 2013) which consists of four phases of analysis: 1. Identification, 2. Screening, 3. Eligibility, and 4. Included. Finally, a conceptual framework was proposed. The framework highlights the relationship between potential Independent variables (IV) and Dependent variables (DV). Finally, the background information underpins this present study. Fig. 1 illustrates the Literature Search Method adopted for the current study.

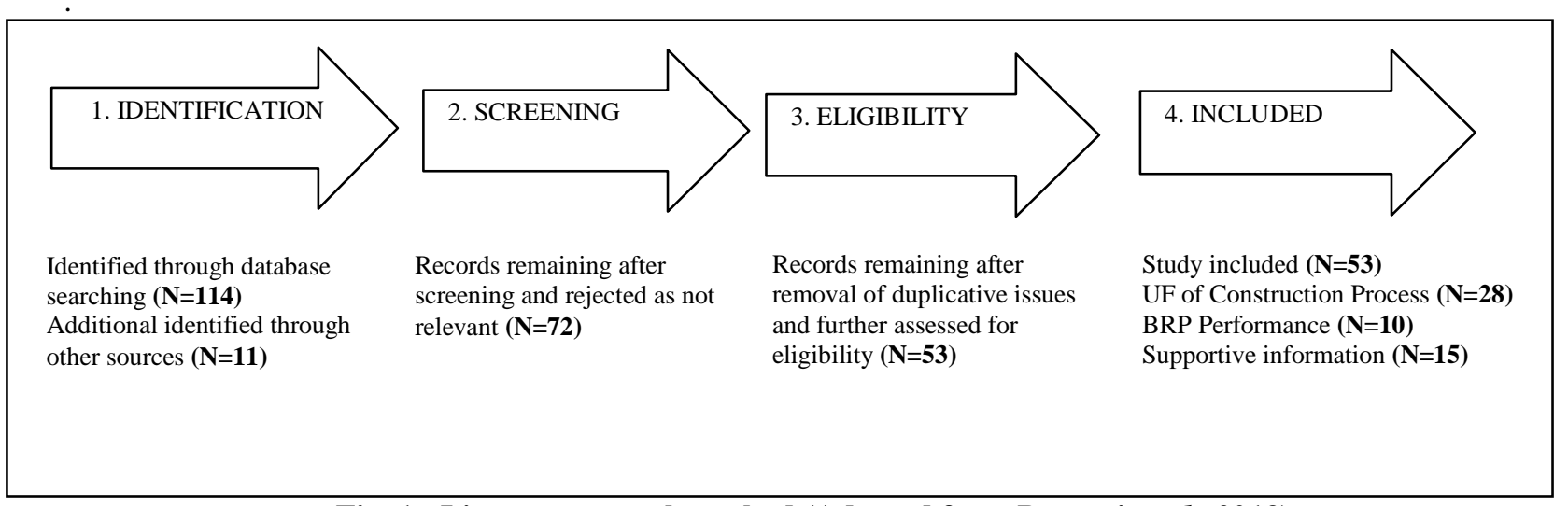

Fig. 1 - Literature search method (Adapted from Papanti et al., 2013)

\section{Findings and Discussion}

Findings from the comprehensive literature review have revealed numerous pieces of evidence that showed the potential variables of UF of construction process and BRP performance. The articles from each category were then further analysed to determine UF of construction process and BRP performance and the relationship between all variables. The first stage of this search initially identified 125 articles; however, after screening, 72 articles were found irrelevant and rejected. Thus, in the eligibility stage, only 53 articles remain, which were included in the study. In this context, $52 \%$ of the 53 articles were related to UF construction process (Table 2) while $20 \%$ were related to BRP performance (Table 3). The remaining articles provided supporting information for the present study with most articles focusing on the issues of managing building refurbishment projects in Malaysia, while a small number of articles discussed managing building refurbishment projects in other Asian and European countries. These articles were published from 1997 to 2019. The findings were further discussed in the following sections. 


\section{UF of Construction Process of BRP}

The construction process of BRP requires a management approach that is capable of handling on site constraints such as access, dust, noise, vibration, restricted space, and change in work program due to the discovery of new issues. Taking into consideration the safety and other statutory regulations and authority matters is also crucial. Additionally, the contractor must have a wide knowledge on the structural integrity of existing building as well as the installation of temporary and permanent services. According to Rahmat (2008), the issues that arise in managing UF of BRP during the construction process need to be overcome to ensure ongoing progress.

\subsection{Structural Works}

Comprehensive structural survey, especially for old building, must be carried out. The extent of the structural problems is not normally discovered until demolition, demounting, enlargements, and strengthening works have started. However, comprehensive building survey may be difficult to be conducted in occupied building (Ali, 2014). The occupants are usually reluctant to allow the surveying activities since such activities disrupt the occupants' daily routine. Hence, it is not always feasible to get the complete and accurate survey in BRP. Overall, the knowledge related to structural works is not widely available and tend to be concentrated only among a few specialist contractors. Therefore, clients only select experienced specialist structural contractor for execution of BRP that involves extensive structural works which is very limited (Ismail, Janipa, Jabar \& Suhaili2018).

\subsection{Mechanical and Electrical Work}

Most of the BRP have high service content. Rahmat (1997) found that service work constitutes more than a third of the contract value, and a higher content of service works entails a higher technological requirement for a majority of the BRP. Thus, the employment of many specialist service engineer and workers becomes necessary. For example, a research by Stone (1976) pointed out that the increase in the service provided in a building further added to erection problems as well as design problems, which may require more detailed drawings. Hence, it is necessary for the work schedules to integrate specialists who are required to be present during the critical stage of decision making. However, a project that involves specialist workers tends to be more difficult to coordinate because they are not easily substituted.

Service works are often conducted at night due to the possibility of electric supply disruption and because the testing is conducted in occupied building. However, other trades are normally continued during the day. This separation and restriction reduces the efficiency of the flow of communication, thus resulting in double handling of works (Irsyad, Halog \& Nepal 2019).

\subsection{Specialist Sub-Contractor and Skilled Labour}

BRP often employs a large number of sub-contractors of different trades that specialize in different technologies and are interdependent of each other. Thus, no party can work in isolation since the timing and duration of their works affect the other parties. The interdependence makes BRP complex considering that more works are required to coordinate different parties involved in the projects. Hence, organizational coordination, tension, and conflicts amongst subcontractors are more likely to occur. Refurbishment managers must ensure that information flows efficiently between all the subcontractors. Hence, it is important for refurbishment managers to have good interpersonal and communication skills. The communication barriers such as failing to communicate, loss of transmission, and physical barriers between the main contractor and numerous subcontractors organisation should be avoided (Adnan, Nawawi, Ismail, \& Mohd Sharif, 2012). Therefore, it is better to create a close long-term relationship between the main contractor and the subcontractors because it builds up trust between them. This makes it easier to integrate the subcontractor into the decision-making process early in the projects (Rahmat, 2008).

The difference between BRP and new build projects is more evident in the degree of intensity of site operations. BRP consists of small labour-intensive operations that are scattered throughout the existing building often with the tenants in occupation. There is also the lack of "as built" drawing to guide the designer and builder and thus in most cases, impromptu decisions need to be made on site based on the skills of the workers. As supported by Rahmat (2008), the use of multi-tasking, skilled, and experienced worker is important in BRP. However, project managers are usually faced with difficulties in the allocation of labour resources to achieve maximum productivity. The site works tend to be "cut and carve" and "touch up" due to the formation of large opening in the wall and floor to accommodate new services; to strengthen structure, walls; to replace old finishes; and to accommodate part of the equipment. Consequently, BRP tends to proceed as a succession of technical problems that requires quick solutions. Frequently, the techniques and methods of repairs have to be uniquely developed for each unit of a building (Adnan et al., 2012; Rahmat, 2008; Rahmat\& Ali, 2010). 


\subsection{People in the Building}

Another challenge for BRP contractors is to work in an occupied building. Continued occupancy of the building during BRP will have a profound influence on the method of construction. Time and non-productive cost that is required to carry out the work tend to increase due to the need of providing temporary protection to the occupants and existing neighbouring buildings or space located nearby the project. Additional cleaning, moving, and covering prior to the start of the work are mandatory, including the cleaning and reinstating of the works area from time to time. All of these tend to cost money even if the clients themselves were to undertake such tasks (Ng, Gong, \& Loveday, 2014).

In most cases, the client may be forced to get involved in the daily activity and the monitoring of the progress of work due to complaints from the occupants or customers. Since the nature of BRP requires the clients to take greater involvement at all stages of the project compared to new build, this involvement should be properly structured and integrated into the project management organisation through a single client representative (Adnan et al., 2012; Rahmat, 2008). However, it is difficult for refurbishment contractor to carry out their work if any managers in the client's organisation initiate a change of order and instruct the site workers to prioritise the interest of customers, which will inevitably affect the contractor's speed and productivity (Ng, Gong, \& Loveday, 2014).

\subsection{Difficulty of Access}

A contractor who is assigned to a BRP in sensitive premises needs to take extra precautions to ensure that the security of the premises is well protected. In addition, the clients or occupants at such premises may impose restriction on the access to certain parts of the building, thus restricting the movement of site operative within the building. Hence, this makes it difficult to have continuity in the work which consequently requires more effort in coordination, planning, and controlling. As mentioned by (Rahmat\& Ali, 2010), traffic restriction in the heavily developed and disturbancesensitive business areas where many BRP are carried out may require all deliveries to be made in the early hours of the morning or late nights; in some cases, the contractor is required to get permission from the neighbours who own the properties adjacent to the BRP. Thus, the contractor should develop a collaborative attitude with the owners of the neighbouring properties. Otherwise, such trespassing might invite hostility from the neighbours and affect the progress of construction works (Yacob et al., 2017).

\subsection{Limited Space}

Space is one of the important elements to be considered in BRP prior to construction. Normally, the planning engineer will visit the site and collect information from the site for planning purposes. New build projects always start with a new and empty piece of land, while BRP have to deal with the lack of space, horizontally and vertically, thus further contributing to the UF of BRP (Adnan et al., 2012; Rahmat, 2008). Space is needed on construction sites for loading and unloading, car parking, and placing of building materials, plant, and equipment. However, most BRP are performed in congested areas and limited space (Tavares, Bernardo, Gaspar, \& Martins, 2016).Under this circumstance, the contractor trades have to rely on the workforce, which is less efficient compared to the machines, thus making it labour intensive that needs a higher degree of supervision and stress. Therefore, all of these negatively affect the productivity of BRP and increase the cost of BRP (Adnan et al., 2012; Ali, Smith, Pitt, \&Choon, 2012).As a result, the BRP tend to be more fragmented. Another option is to work overtime and conduct the delivery of material at the end of working hours to ensure that the progress of the works is on track (Rahmat, 2008). Apart from that, the project manager must take into consideration the safety issues and closely monitor the unsocial working hours.

\subsection{Noise, Dust and Vibration}

Noise and dust control are two of the most difficult management tasks faced by refurbishment managers. The effects of noise, dust, and vibration on the occupants of a building are often underestimated. This is especially true for building with high content of demolition and service works. Moreover, these problems could be very difficult to manage for hospital refurbishment project. In this case, they constitute very significant problems which can be solved only by careful selection of equipment and techniques together with good communication, warnings, and planning. In the case of the construction workers sharing the same space with the occupants of the building, several management writers (e.g. Ho, 2012; Ward, Azhar, \&Khalfan, 2017) described this situation as independently pooled in the same place, whereby the participants involved in the construction project share an independent resource. Moreover, sharing the same limited space requires the participants to be tolerant and to adopt the spirit of give and take and respect each other's needs. 


\subsection{Existing Materials}

UF of BRP can also be derived from the availability of materials, which can have a major impact on construction process (Ballarini, Corrado, Madonna, Paduos, \&Ravasio, 2017). One main problem in BRP is to maintain aesthetical values of the building. The contractor might face difficulties in matching existing components and materials due to the inability to procure the original materials. For example, it can be very difficult to find wall tiles of exact same colour and size as the original ones. Moreover, some of the material may be made to metric instead of imperial dimensions. Hence, newer materials with different performance may have to be used to replace or match the existing ones. Aesthetically, this is undesirable. The client may not be happy to replace the original materials entirely (Rahmat, 2008). In addition, special design and workmanship skills are needed to match new works with old ones. Therefore, this problem is more critical in conservation work (Adnan et al., 2012). Overall, a review of the past literatures shows that the UF of construction process tend to affect the performance of BRP. In essence, a major problem with the previous research was that no attempt was made to relate with BRP performance. Therefore, the focus of this research was to determine the UF variable that is potentially related to the construction process and performance of BRP. Through the literature search, nine uncertainty factors associated with BRP performance were identified

\subsection{Conflicts}

The knowledge on the factors of complexity and uncertainty in refurbishment projects that cause conflict need to be systemically managed to enable successful project implementation. The complexity and uncertainty factors that cause conflict are design changes, unforeseen project conditions, inaccurate design information, errors in design, and lack of design information. Conflicts with the occupants are more likely to occur when the contractors fail to consider the occupants' need for space to carry out their daily activities. Consequently, the clients have the rights to stop the BRP if they found that their daily business activities are severely affected (Kamaruzzaman, Egbu, Zawawi, Ali, \& CheAni, 2011; Noori et al., 2016; Rahmat, 2008)

\subsection{Human Factors}

The human impact factor is the relationships between people and the systems within which they interact by improving efficiency, creativity, productivity, and job satisfaction, with the goal of minimising errors (Kohn, Corrigan, \& Donaldson, 1999). The relationship between human impact factors and the success or failures of a construction project have already been researched extensively. According to (Orando \& Marcellus, 2013), consideration of human impact factors is crucial for increasing efficiency and performance in the construction industry. This is especially so when projects are complex, which affect the nature of the tasks involved. In addition, Wong (2007) commented that people are important in the building construction project environment, and that many projects have revealed frustrations caused not by deficiencies in the method or poorly constructed schedule of works, but rather by the people involved in the project (Yacob, Saruwono, Ismail, \& Pheng, 2018)

\subsection{Leadership Qualities among Project Managers}

As defined by De Haan, Jansen \&Lighart (2015), leadership quality is the combination of a person's strong characteristics and an organisation's vision and mission to achieve specific goals. On the other hand, the role of refurbishment project managers refers to the application of skills and knowledge throughout the project life cycle (Rahmat, 1997). However, there are some overlaps across management levels that are associated with forecasting and planning, handling conflicts and crisis, tenant welfare, team building, and the decision making process (Noori et al., 2016). Nevertheless, these tasks are totally different, reflecting the uncertain nature and relatively higher levels of complexities compared to new building construction management (Yacob et al., 2017). Based on previous studies such as a study by Cohen and March (1974), leadership is the art of influencing others to reach their maximum performance level to accomplish any task. Murphy (2013) had emphasised the importance of selecting the right people to achieve organisational success. Furthermore, in the rapidly paced, globally competitive marketplace, leaders must adopt a new mindset (den Hartog, van Muijen, \& Koopman, 1997). Ain, Nasaruddin\& Rahman (2016) agreed that the implementation of projects requires construction leaders who can play a key role in ensuring that the process commenced smoothly so that it would positively contribute to the project's performance. Yacob et al. (2017) concurred that to manage the various uncertainties, specific leadership qualities among project managers are essential. Meanwhile, Montequin, Nieto, Ortega, \& Villanueva (2015) revealed that uncertain situations could severely expose the quality of leadership. Normally, in such circumstances, a project manager would adapt accordingly and act decisively while acting as a role model for their followers (Yacob, Saruwono, \& Ismail, 2018). A summary of UF of construction process is listed in Table 2. 
Table 2 - Uncertainty Factor (UF) of construction process of Building Refurbishment Project (BRP)

\begin{tabular}{|c|c|}
\hline Item and Dimension & Authors \\
\hline $\begin{array}{l}\text { 1. Structural Works } \\
\text { The extent of the structural problems is not normally discovered until the } \\
\text { demounting, enlargements, and strengthening works have started }\end{array}$ & $\begin{array}{l}\text { Rahmat (2008), Ali ( 2014) \& } \\
\text { Ismail et al (2018) }\end{array}$ \\
\hline $\begin{array}{l}\text { 2. Mechanical and Electrical Work } \\
\text { The increase in the service provided in a building further added to erection } \\
\text { problems as well as design problems which may require more detailed } \\
\text { drawings }\end{array}$ & $\begin{array}{l}\text { Stone (1976), Rahmat \& Ali } \\
\text { (2009), Yacob et al., (2018) \& } \\
\text { Irsyad et al (2019) }\end{array}$ \\
\hline $\begin{array}{l}\text { 3. Specialist Sub-Contractor } \\
\text { Works are required to co-ordinate different parties involved in the projects. } \\
\text { Hence, organizational coordination, tension, and conflicts amongst } \\
\text { subcontractors are more likely to occur }\end{array}$ & $\begin{array}{l}\text { Rahmat (2008) \& Adnan et al., } \\
\text { (2012) }\end{array}$ \\
\hline $\begin{array}{l}\text { 4. Skilled Labour } \\
\text { Consist of hand-on works and small labour-intensive operations that are } \\
\text { scattered throughout the existing building often with the house owner and } \\
\text { tenant }\end{array}$ & $\begin{array}{l}\text { Adnan et al., (2012) \& Rahmat \& } \\
\text { Ali, (2010) }\end{array}$ \\
\hline $\begin{array}{l}\text { 5. People in the Building } \\
\text { Continued occupancy of the building during BRP will have a profound } \\
\text { influence on the method of construction. Time and non-productive cost that is } \\
\text { required to carry out the work } \\
\text { 6. Difficulty of Access }\end{array}$ & $\begin{array}{l}\text { Ng, Gong, \& Loveday (2014), } \\
\text { Adnan et al., (2012) \& Rahmat } \\
\text { (2008) }\end{array}$ \\
\hline $\begin{array}{l}\text { Such premises may impose restriction on the access to certain parts of the } \\
\text { building, thus restricting the movement of site operative within the building. } \\
\text { Hence, this makes it difficult to have continuity in the work which } \\
\text { consequently requires more effort in coordination, planning, and controlling } \\
\text { 7. Limited Space }\end{array}$ & $\begin{array}{l}\text { Rahmat \& Ali (2010), Yacob et al., } \\
\text { (2018) \&Egbu (2010) }\end{array}$ \\
\hline $\begin{array}{l}\text { Space is needed on construction sites for loading and unloading, car parking } \\
\text { and placing building materials, plant and equipment. However, most BRP are } \\
\text { carried out in congested areas and limited space }\end{array}$ & $\begin{array}{l}\text { Tavares et al., (2016), Adnan et al., } \\
\text { (2012) \& Ali et al., (2012) }\end{array}$ \\
\hline $\begin{array}{l}\text { 8. Noise, Dust and Vibration } \\
\text { Effects of noise, dust, and vibration on the occupants of a building are often } \\
\text { underestimated } \\
\text { 9. Existing Materials }\end{array}$ & $\begin{array}{l}\text { Ho, (2012), Ward et al., (2017) } \\
\text { \&Kamaruzzaman et al.,(2011) }\end{array}$ \\
\hline $\begin{array}{l}\text { Newer materials with different performance may have to be used to replace or } \\
\text { match the existing ones. Aesthetically, this is undesirable. The client may not } \\
\text { be happy to replace the original materials entirely } \\
\text { 10. Conflicts }\end{array}$ & $\begin{array}{l}\text { Ballarini et al., (2017) \& Adnan et } \\
\text { al., (2012) }\end{array}$ \\
\hline $\begin{array}{l}\text { Factors that causes conflict are design changes, unforeseen project conditions, } \\
\text { inaccurate design information, errors in design, and lack of design } \\
\text { information. Moreover, the conflicts with the occupants are more likely to } \\
\text { occur when the contractors fail to consider the needs of the occupants for } \\
\text { space to carry out their daily activities }\end{array}$ & $\begin{array}{l}\text { Kamaruzzaman et al., (2011) } \\
\text { Noori et al., (2016), Saurin, } \\
\text { Rooke, Koskela, \& Kemmer (2013) } \\
\text { \&Bradberry (2015) }\end{array}$ \\
\hline $\begin{array}{l}\text { 11. Human Factors } \\
\text { Human Factor is crucial for increasing efficiency and performance in the } \\
\text { construction industry. This is especially so when projects are complex and } \\
\text { affecting the nature of the tasks involved }\end{array}$ & $\begin{array}{l}\text { Yacob et al., (2018), Orando\& } \\
\text { Marcellus (2013) \& Sunikka-blank, } \\
\text { Chen, \&Britnell (2012) }\end{array}$ \\
\hline $\begin{array}{l}\text { 12. Leadership Qualities among Project Managers } \\
\text { Uncertain situations could severely expose the quality of leadership. Normally, } \\
\text { in such circumstances, a project manager would adapt accordingly and act } \\
\text { decisively while setting a role model example for their followers }\end{array}$ & $\begin{array}{l}\text { Yacob et al., (2018), De Haan et } \\
\text { al., (2015) \& Ain et al., (2016) \& } \\
\text { Udhayakumar and P. Karthikeyan } \\
\text { (2014) }\end{array}$ \\
\hline
\end{tabular}

\section{BRP Performance}

As reported in the existing research, UF of construction process is one of the reasons for poor BRP performance. This is because BRP involves redesign, structural modifications, high contents of service works, as well as energy efficiency and sustainability issues. These can be sensitive, dangerous, and require the implementation of additional 
safety precautions (Karlsson\&Svensson, 2015). In particular, managing UF of BRP requires greater involvement of all participants. Although, the decision making process can reduce fragmentation during planning and design to the construction process, this has not been practised because over half of the projects have exceeded the budget and time targets (Rahmat\& Ali, 2010).

Josephson and Lindstrom (2007) and Thomas et al. (2002) agreed that the performance of a project could be measured using numerous parameters related to cost, time, and quality. Specifically, the parameters that affect the performance of refurbishment projects include time variances, cost variances, percentage of variations in work, average number of complaints received, and average number of non-compliance (CIDB, 2014; Mokhtar, 2015; Tan, Olanrewaju, \& Lee, 2016; Tang \& Ng, 2014). BRP performance is summarised in the following Table 3.

Table 3 - BRP Performance

\section{Item and Dimension}

\section{Cost variances}

Cash flow, change in order, and items absent in Bills of Quantities. Cost is often higher than specified in the original contract due to lack of design and specification details, and absence of the Bills of Quantities during tendering

\section{Time variances}

Payment issues and communication with clients and consultants. Payment not made for variations in work by the client, which results in the unhealthy management of cash flow by contractors, which in a continuous manner will cause time variance and the contractor will suffer monthly income loss

\section{Variation work}

Decision-making by clients and consultants. The absence of the Bills of Quantities during tendering can give rise to high variations in the works

\section{Number of complaints by clients and occupants' satisfaction}

The effectiveness of the refurbishment process strongly depends on the quality of communications between the parties involved that can reduce failure and smoothen project activities. Poor quality of work can lead to complaints from the client. The focus must be on the satisfaction of occupants and socio-cultural issues that may arise during refurbishment

\section{Number of Non-Conformance Report}

Quality of work, communication skills, and client satisfaction. Poor planning and control will delay refurbishment projects. Specifically, a wrong work sequence causes the contractor to incur higher costs, poor quality of work, increased in the percentages of work and additional costs, as well as non-conformance report

\author{
Author \\ Josephson \& Lindstrom, \\ (2007), Thomas et al., \\ (2002) \& Ali, Peng, Yong, \\ \&Chieng, (2014) \\ Josephson \& Lindstrom \\ (2007), Thomas et al., \\ (2002), Ali et al., (2014) \& \\ Strachan (2013) \\ Josephson \& Lindstrom \\ (2007), Thomas et al., \\ (2002) \& Ali et al., (2014) \\ Josephson \& Lindstrom \\ (2007), Thomas et al., \\ (2002) \& Ali et al., (2014), \\ Cohen \& March, (1974), \\ Noori et al., (2016) \\ \&Karlsson\&Svensson \\ (2015) \\ Josephson \& Lindstrom \\ (2007), Thomas et al., \\ (2002), Ali et al., (2014) \& \\ Mokhtar (2015)
}

\section{Proposed Conceptual Framework}

A conceptual framework is an analytical tool with several variations and contexts, which is used to make conceptual distinctions and organize ideas. Hence, based on the findings of the comprehensive literature review, the dataset can be grouped into two main variables as follows: UF of construction process as the independent variable (IV) and BRP performance as the dependent variable (DV). These two factors are incorporated in a conceptual framework (refer to Fig. 2).The proposed conceptual framework has been constructed based on variables and items that have been determined according to previous studies and findings of the literature review. Although many studies have been recently conducted on the planning and design process that can effectively manage uncertainties to improve the performance of refurbishment projects, the UF of construction process must also be considered. There is no consensus yet on how best these constructs can be incorporated to manage the UF of BRP better.

The current study is focused in addressing the limitations of the previous research conducted by (Hodgson, White, \& White, 2003; Josephson \& Lindstrom, 2007; Yacob, Saruwono, \& Ismail, 2018). It aims to provide the basis information for further research into managing the UF of BRP with an emphasis on construction process that can influence BRP performance as well as to identify the dependency relationship from different points of view. 


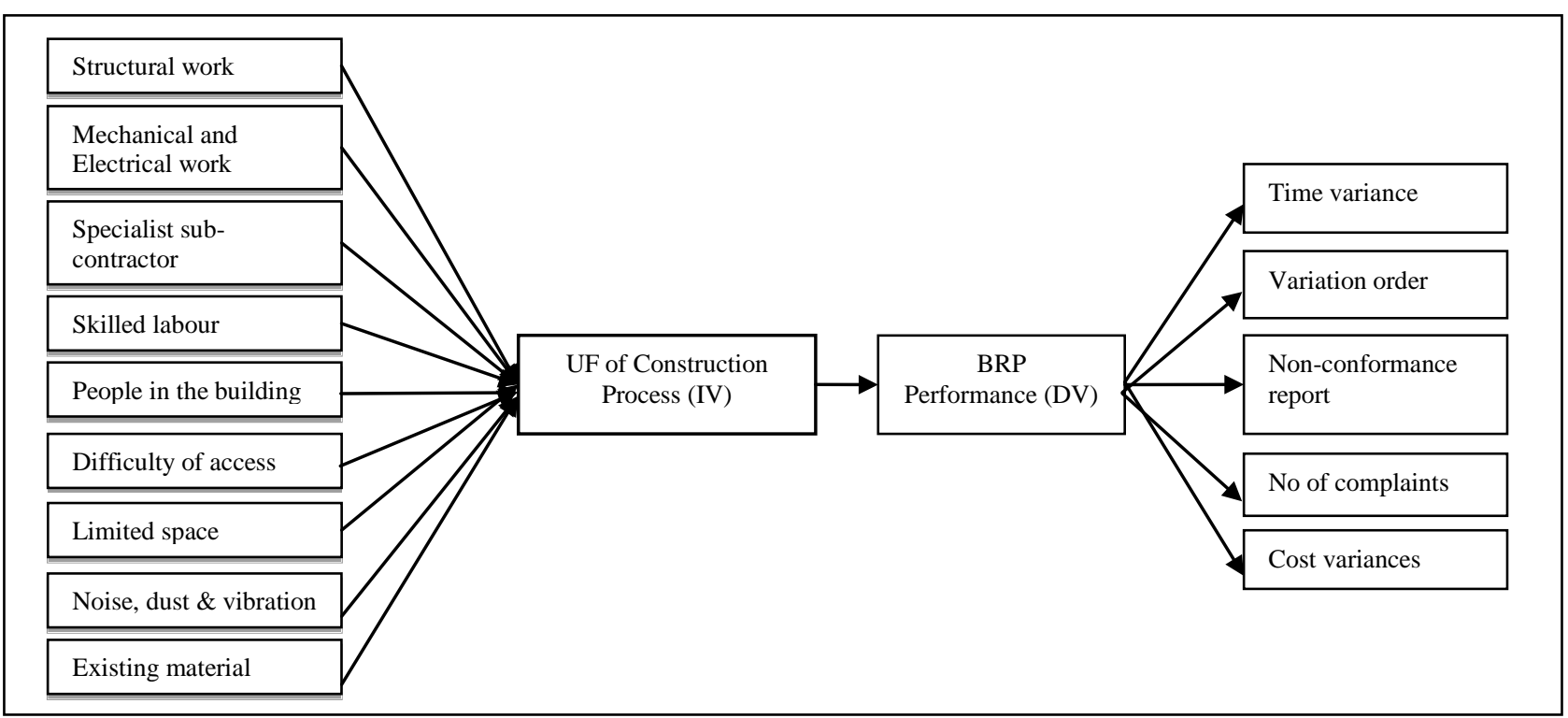

Fig. 2 - Conceptual framework: Relationship between UF and BRP performance

\section{Conclusion and Recommendation}

This paper has provided an overview of the existing literature, focusing on the relationships between UF of construction process and BRP performance. Nine UF of construction process were determined, which were associated with five identified BRP performance. In addition, a knowledge gap was revealed that only a few studies have been conducted specifically on managing UF of construction process. Nonetheless, further empirical research is recommended to justify and validate the above findings.

This study is expected to contribute new information to the existing body of knowledge (refer to Table 3). The first area of contribution is conceptual, which is a replication of a previous research by Rahmat\& Ali, (2010) that have completely extended the concept of UF from planning and design to construction process of BRP. The second area is methodological, which is to verify and validate the scale to measure the dimensions of relationship between UF of construction process and BRP performance. Additionally, the methodology can be extended by statistical testing of the relationship amongst variables. The third area relates to empirical contributions, in which research analysis can be conducted to extend and verify the integrated effect of UF of construction process and BRP performance. The ability to manage UF of construction process will influence BRP performance and help to reduce cost variances, time variances, and quality. Lastly, future studies can also be conducted to replicate and test the proposed conceptual model.

Table 3 - Areas of contributions

\begin{tabular}{|c|c|c|c|}
\hline \multirow{2}{*}{$\begin{array}{l}\text { Areas of } \\
\text { Contributions }\end{array}$} & \multicolumn{2}{|c|}{ Level of Contributions } & \multirow[t]{2}{*}{ Impact } \\
\hline & Replication & Extension & \\
\hline Conceptual & $\begin{array}{l}\text { Clarify concept of UF of } \\
\text { construction process of BRP }\end{array}$ & & $\begin{array}{l}\text { Literature \& } \\
\text { Body of knowledge }\end{array}$ \\
\hline Methodological & $\begin{array}{l}\text { Verify the validity and reliability } \\
\text { of scales to measure dimensions of } \\
\text { relationship between UF of } \\
\text { construction process and BRP } \\
\text { performance }\end{array}$ & & Methodology \\
\hline Empirical & & $\begin{array}{l}\text { Verify integrated effect of the } \\
\text { following relationships: } \\
\text { - Between UF of Construction } \\
\text { process and BRP performance }\end{array}$ & $\begin{array}{l}\text { Literature \& } \\
\text { Body of knowledge }\end{array}$ \\
\hline
\end{tabular}




\section{Acknowledgement}

The authors would like to express their gratitude to the Faculty of Architecture, Planning \& Surveying, Universiti Teknologi MARA (UiTM) for the assistance and the information provided to ensure the success of this study.

\section{References}

Adnan, H., Nawawi, A. H., Ismail, F \& Mohd Sharif, S. (2012). Holistic construction project management (1st ed.), Selangor: UiTM Press.

Ain, N., Ngah, N \& Ismail, A. R. (2016). Leadership quality for Malaysia construction leader to steer a success construction project. MATEC Web of Conference, EDP Sciences, 47, 04006.

Ali, A, S. (2014).Complexity in managing refurbishment design process: Malaysian experience. MATEC Web of Conferences. EDP Sciences. 15, 01030.

Ali, A. S., Zulkiflee, A. S., \& MR, P. (2010). A study of design performance of refurbishment projects in Malaysia. Journal of Asian Architecture and Building Engineering, 9(2), 323-329.

Ali, A, S., Kamaruzzaman, S \& Salleh, H. (2009). The characteristics of refurbishment projects in Malaysia. Facilities, 27(1/2), 56-65.

Ali, A, S., Peng, C., Yong, A. L \& Chieng, S. (2014). Managing refurbishment projects through selection of procurement system: The Case of Malaysia. European Journal of Sustainable Development, 3(4), 311-322.

Ali, A, S., Smith, A., Pitt, M \&Choon, C. H. (2012). Contractor's perception of factors contributing to project delay: Case studies of commercial projects in Klang Valley, Malaysia. Journal of Design and Build Environment, 7(1), 17.

Ali, A, S.,\& Zakaria, R. (2012). Complexity of statutory requirements: Case study of refurbishment projects in Malaysia. Journal of Building Performance, 3(1), 49-54.

Ballarini, I., Corrado, V., Madonna, F., Paduos, S \&Ravasio, F. (2017). Energy refurbishment of the Italian residential building stock: Energy and cost analysis through the application of the building typology. Energy Policy, 105, 148160 .

Bradberry, T. (2015). 11 strategies successful leaders use to overcome uncertainty. Online available; Retrieved on September 12, 2016, from https://www.weforum.org/agenda/2015/09/11-strategies-successful-leaders-use-toovercome-uncertainty/

CIDB. (2014). Construction statistics quarterly bulletin. Online available; Retrieved on October 16, 2016, from http://www.cidb.gov.my.

CIDB. (2015). Construction projects, contractors and construction personnel construction projects. Online available; Retrieved on October 20, 2017, from http://www.cidb.gov.my.

Cohen, M. D \& March, J. G. (1974). Leadership and ambiguity: The American college president. McGraw-Hill Book Company, Hightstown, New Jersey ERIC Number: ED088354. Pp-283.

De Haan, T., Jansen, P \& Lighart, P. (2015). Sustainable leadership: Talent requirement for sustainable enterprises. Reynolds Associates. Pp-4-13.

Den Hartog, D. N., Van Muijen, J. J \& Koopman, P. L. (1997). Transactional versus transformational leadership: An analysis of the MLQ. Journal of Occupational and Organizational Psychology, 70(1), 1.

Egbu, C. O. (2010). Skills, knowledge and competencies for managing construction refurbishment works. Construction Management and Economics, 17(1), 29-43.

Ho, F. (2012). Managing multiple contractors on refurbishment projects; Construction and development. Online available; Retrieved on October 25, 2017, from https://www.lexology.com.

Hodgson, P., White, R \& White, R. (2003). Facing the unknown: what are leaders for if not to manage uncertainty. Online available; Retrieved on September 12, 2016, from http://iveybusinessjournal.com/publication/facing-theunknown-what-are-leaders-for-if-not-to-manage-uncertainty/

Irsyad, M. I., Halog, A \& Nepal, R. (2019). Renewable energy projections for climate change mitigation: An analysis of uncertainty and errors. Renewable Energy, 130, 536-546.

Ismail, F., Janipa, N. I., Jabar, I. L \&Suhaili, F. N. (2018). Parameters of Uncertainty among Quantity Surveyors for 
Heritage Conservation Refurbishment Projects: The Case Study Approach. Journal of Surveying, Construction and Property (JSCP), 9, 1-35.

Jens. (2013). International public organisations uncertainty, complexity: Today's reality for leaders in international public organisations. Management Centre Europe, (1): 01-07.

Josephson, P. E. \& Lindstrom, J. (2007). Measuring performance in construction projects. Proceeding of the CIB world building conference on construction for development. Cape Town, South Africa, pp 383-394.

Kamaruzzaman, S. N., Egbu, C. O., Zawawi, E. M. A., Ali, A. S \&CheAni, A. I. (2011). The effect of indoor environmental quality on occupants' perception of performance: A case study of refurbished historic buildings in Malaysia. Energy and Buildings, 43(2-3), 407-413.

Karlsson, E \&Svensson, M. (2015). The refurbishment process from of a sustainability and energy efficient point of view. Online available; Retrieved on 23 May 2017, from http://hj.diva-portal.org.

Kohn, L. T., Corrigan, J. M \& Donaldson, M. S. (1999). To err is human: building a safer health system. Online available; Retrieved on 24 May 2015.from http://books.nap.edu/html/.

Mokhtar, S. N. (2015). Identifying activities that contribute to the generation of refurbishment waste at site identifying activities that contribute to the generation of refurbishment waste at site. Online available; Retrieved on 12 April 2016 , from https://doi.org/10.13140/RG.2.1.1122.3765

Montequin, V. R., Nieto, A. G., Ortega, F., \& Villanueva, J. (2015). Managerial Style Profiles of Successful Project Managers: A Survey. Procedia Computer Science, 64, 55-62.

Murphy, C. (2013). Sustainable Refurbishment: New policy initiatives for New Zealand's leaking buildings. Government legislative initiatives.Online available; Retrieved on 23 May 2017, fromhttp://unitec.researchbank.ac.nz/

Ng, S. T., Gong, W \& Loveday, D. L. (2014). Sustainable refurbishment methods for uplifting the energy performance of high-rise residential buildings in Hong Kong. Procedia Engineering, 85(ii), 385-392.

Noori A., Saruwono M., Adnan H., Rahmat I. (2016). Conflict, complexity, and uncertainty in building refurbishment projects. In: Yusoff M., Hamid N., Arshad M., Arshad A., Ridzuan A., Awang H. InCIEC 2015. Springer, Singapore. 251-258.

Odimabo. (2018). An insight into the process, tools and techniques for construction risk management.Intechopen.79459, 5-9.

Orando, M \& Marcellus. (2013). The influence of human behaviour factors on construction productivity. Online available; Retrieved on 23 Marh 2015, from http://scholar.ufs.ac.za:8080/xmlui/handle/11660/1430

Papanti, D., Schifano, F., Botteon, G., Bertossi, F., Mannix, J., Vidoni, D., Bonavigo, T. (2013). “Spiceophrenia”: a systematic overview of "Spice"-related psychopathological issues and a case report. Human Psychopharmacology: Clinical and Experimental, 28(4), 379-389.

Quah. L.K. (1992). Comparative variability in tender bids for refurbishment and new build work. Journal of Construction Management and Economics, 10.263-269.

Rahmat, I. (1997). The Planning and Control Process of Refurbishment Projects. Journal of Chemical Information and Modeling, 53(9), 1689-1699.

Rahmat, I. (2008). Managing refurbishment project. University Publication Centre (UPENA) UITM. Shah Alam 2008.

Rahmat, I., \& Ali, A. S. (2009). The design process of building refurbishment projects. Online available; Retrieved on 25 May 2016. From http://repository.um.edu.my/61356/1/MICRA1.pdf

Rahmat, I \& Ali, A S. (2009). Uncertainty in the design process of refurbishment projects. Built Environment Journal, 6: 35-43.

Rahmat, I., \& Ali, A. S. (2010). The involvement of the key participants in the production of project plans and the planning performance of refurbishment projects. Journal of Building Appraisal, 5(3), 273-288.

Saurin, T. A., Rooke, J., Koskela, L \& Kemmer, S. (2013). Guidelines for the management of complex socio-technical systems: An exploratory study of a refurbishment project.IGLC-21, (July), 13-22.

Stone, P. A. (1976). Building economy: Design, production, and organisation: a synoptic view. 2nd edition. Pergamon press, Oxford.

Strachan, M. (2013). Energy-led, non-domestic building refurbishment: Decision support for a whole-building approach to improvement of operational performance. Online available; Retrieved on 12 June, from 
http://www.ros.hw.ac.uk/bitstream/handle/10399/2724/StrachanM_0713

Sunikka-blank, M., Chen, J., \& Britnell, J. (2012). Improving energy efficiency of social housing areas: a case study of a retrofit achieving an " a " energy performance rating in the UK improving energy efficiency of social housing areas : A case study of a retrofit achieving an “ a ” energy performance. European Planning Studies, 37-41.

Tan, S. Y., Olanrewaju, A \& Lee, L. T. (2016). Maintenance of heritage building: A case study from Ipoh. Online available; Retrieved on 25 June, from, http://www.matecconferences.org/articles/matecconf/pdf/2016/10/matecconf.

Tang, Z., \& Ng, S. T. (2014). Sustainable Building Development in China - A System Thinking Study. Procedia Engineering, 85, 493-500.

Tavares, P., Bernardo, H., Gaspar, A., \& Martins, A. (2016). Control criteria of electro chromic glasses for energy savings in Mediterranean buildings refurbishment. Solar Energy, 134, 236-250.

Thomas, S.R., Macken, C.L., Chung, T. H., \& Kim, I. (2002). Measuring the impact of the delivery system on project performance: design-build and design-bid-build. Construction Industry Institute. Austin, 02-840.

Udhayakumar and P. Karthikeyan. (2014). Expected leadership qualities for a project manager to manage construction project site. International journal of innovative research and development, 3, 57-61, (2014).

Ward, A. E., Azhar, S., \&Khalfan, M. (2017). Construction in Occupied Spaces. Slovak Journal of Civil Engineering, 25(2), 15-23.

Wong, Z. (2007). Human factors in project management: concepts, tools, and techniques for inspiring teamwork and motivation, London: Wiley. Online available; Retrieved on 23 Feb 2016. From: https://epdf.tips/human-factors-inproject-management-concepts-tools-and-techniques-for-inspiring-.html

Yacob, R., Rahmat, I., Saruwono, M., \& Ismail, Z. (2017). Effects of Uncertainty Factors and Refurbishment Projects Performance in Relation to Leadership Quality of Project Managers. Journal of Building Performance, 8(1).

Yacob, R., Saruwono, M., \& Ismail, Z. (2018). A Review of Leadership Qualities among Building Refurbishment Project Managers. International Journal of Engineering \& Technology, 7, 126-131.

Yacob, R., Saruwono, M., Ismail, Z., \& Pheng, L. S. (2018). Influence of Human Factors on the Uncertainties of Refurbishment Projects : A Proposed Conceptual Approach. Journal of Engineering (UKM) 2019-SI-2(1). 